\title{
Pengembangan $e$-modul berorientasi KKNI pada perkuliahan Pendidikan Kewarganegaraan Universitas Sriwijaya
} \section{*korespondensi penulis

\begin{tabular}{ll}
\hline \multicolumn{2}{l}{ Informasi artikel } \\
\hline Sejarah artikel: & \\
Diterima & $: 27-02-2018$ \\
Revisi & $: 14-06-2018$ \\
Dipublikasikan & $: 31-10-2017$ \\
\hline
\end{tabular}

Husnul Fatihaha, ${ }^{\text {a* }}$, Sri Artati Waluyati ${ }^{\mathrm{b}, 2}$, Camelliac, 3

a, b, c Fakultas Keguruan dan Ilmu Pendidikan, Universitas Sriwijaya, Indralaya, Indonesia

${ }^{1}$ husnulfatihah@fkip.unsri.ac.id*;2 sriartatiwaluyati@yahoo.co.id; 3 Liacamel47@yahoo.com

Kata kunci:

e-modul

KKNI

pendidikan kewarganegaraan \begin{abstract}
ABSTRAK
Penelitian ini bertujuan untuk mengembangkan e-modul berorientasi KKNI pada perkuliahan pendidikan kewarganegaraan dan dampak potensial e-modul berorientasi KKNI terhadap hasil belajar mahasiswa pada perkuliahan pendidikan kewarganegaraan. Penelitian pengembangan ini menggunakan model ADDIE. Subjek penelitian yang ditetapkan adalah mahasiswa ilmu komputer dan jaringan yang mengambil Mata Kuliah Pendidikan Kewarganegaraan pada semester Ganjil 2017-2018. Berdasarkan hasil analisis dan pembahasan maka disimpulkan e-modul berorientasi KKNI yang dikembangkan ini valid, praktis dan berefek potensial dalam meningkatkan pemahaman mahasiswa terhadap materi. Terkategorikan valid setelah mendapatkan hasil $92 \%$ dari validasi ahli bahasa dan 92\% ahli materi. Kemudian dalam tiga kali tahapan uji coba mendapatkan tanggapan yang positif dari para mahasiswa penggunaannya. Dan pada uji coba lapangan terdapat $N$-gain 0,6 dengan kategori sedang dari perbandingan pre tes dan pos tes yang dilakukan.

\section{ABSTRACT}

This study aims to develop KKNI-oriented e-modules in lectures on citizenship education and the potential impact of KKNI-oriented $e$ modules on student learning outcomes in lectures on citizenship education. This developmental research uses the ADDIE model. The research subjects were computer science and network students who took Citizenship Education Courses in the Odd Semester 2017-2018. Data were collected through documentation techniques, questionnaires, observations, and tests. Furthermore, the data analysis technique used is quantitative data analysis. In addition to the data from the preliminary study, questionnaire data related to product validity were also analyzed using descriptive analysis. Based on the results of the analysis and discussion, it was concluded that the KKNI-oriented e-module developed was valid, practical and had a potential effect in increasing students' understanding of the material. It is categorized as valid after getting $92 \%$ results from linguist validation and $92 \%$ material experts. Then in the three stages of the trial, there was a positive response from the students. And in the field trials, there are $N$-gain 0.6 with a moderate category from the comparison of the pre-test and post-tests conducted.
\end{abstract}

Keywords:

e-modul

KKNI

civic education

\section{Copyright (C) 2018 Husnul Fatihah}

\section{Pendahuluan}

Kemajuan dan perkembangan teknologi memengaruhi seluruh aspek kehidupan masyarakat, dari bidang politik, ekonomi, sosial budaya, pendidikan, pertahanan dan keamanan dan bidang kesehatan. Terdapat pengaruh positif dan negatif, diantara pengaruh positif adalah semua berita dan informasi apapun di belahan dunia dapat dengan mudah diakses. Hampir semua kalangan dari anak-anak sampai dewasa sudah mampu mengakses informasi baik melalui teknologi komputer dan handphone yang dilengkapi dengan internet. 
Aspek pendidikan juga turut serta memanfaatkan kemajuan teknologi, diantaranya pendidik dan peserta didik dapat dengan mudah mengetahui serta mempelajari ilmu pengetahuan yang mereka butuhkan dimana saja dan kapan saja, teknologi juga membantu pendidik menyampaikan materi dengan lebih efektif dan efisien. Pengaruhpengaruh positif tersebut mendukung terwujudnya proses pembelajaran yang tertuang dalam peraturan pemerintah No 32 tahun 2013 pasal 19 ayat 1 yang berbunyi "proses pembelajaran pada satuan pendidikan dilaksanakan secara interaktif, inspiratif, menyenangkan, menantang, memotivasi, peserta didik untuk berpartisipasi aktif, serta memberikan ruang yang cukup bagi pra aksara, kreativitas, dan kemandirian sesuai dengan bakat, minat dan perkembangan fisik dan psikologis peserta didik".

Salah satu isi dari undang-undang sistem pendidikan nasional tersebut menyatakan bahwa dalam proses pembelajaran pendidik hendaklah menyiapkan dan menyediakan $e$ modul atau modul yang interaktif dan inovatif, sehingga siswa tertarik dan termotivasi untuk membaca dan mempelajari. Untuk menyiapkan modul yang interaktif dan inovatif pendidik dituntut untuk mampu menggunakan dan memanfaatkan kemajuan teknologi. Namun, masih banyak pendidik baik dari tingkat perguruan tinggi maupun sekolah menengah dan dasar yang belum mampu memanfaatkan kemajuan teknologi, dalam penyampaian e-modul pembelajaran. E-modul yang digunakan hanya berupa buku atau modul cetak sehingga masih kalah menarik dengan informasi lain yang dikemas secara elektronik.

Mata kuliah Pendidikan Kewarganegaraan (PKn) adalah mata kuliah yang wajib diambil oleh setiap mahasiswa di Universitas Sriwijaya pada semester ganjil atau semester genap. Mengingat mata kuliah PKn adalah mata kuliah wajib, maka memaksimalkan proses pembelajarannya merupakan hal yang sangat penting. Salah satu cara memaksimalkan proses pembelajaran adalah dengan pengembangan modul apalagi memperhatikan belum ada pengembangan e-modul pada mata kuliah
PKn. Modul yang akan dikembangkan dalam penelitian ini adalah modul dengan pendekatan elektronik yang disebut dengan $e$ modul.

Pengembangan e-modul ini dirancang dengan menggunakan program komputer (software) flash flip book. Pada awalnya flip book adalah salah satu jenis animasi klasik yang dibuat dari setumpuk kertas menyerupai buku tebal, pada setiap halamannya digambarkan proses tentang sesuatu yang nantinya proses tersebut terlihat seperti bergerak. Seiring dengan perkembangan zaman telah banyak vendor yang menyediakan perangkat lunak untuk membuat media flip book, misalnya Macromedia yang mengeluarkan software flash flip book. Dengan software ini media pembelajaran yang disajikan tidak hanya menampilkan teks, tetapi juga video, suara dan gambar. Dengan demikian mahasiswa bisa mengakses pelajaran kapan pun dan di mana pun mereka berada, tanpa harus membawa buku-buku dan modul cetak pembelajaran. Sehingga diharapkan mahasiswa semakin senang belajar dan berdampak meningkatnya nilai hasil belajarnya.

Konten atau materi e-modul yang akan dikembangkan ini berorientasi Kerangka Kualifikasi Nasional Indonesia (KKNI) sebagaimana pada Peraturan Presiden No 8 tahun 2012. Peraturan presiden mengenai KKNI menjelaskan bahwa lulusan setara S1 harus memiliki beberapa kompetensi antara lain: (1) mampu mengaplikasikan bidang keahliannya dan memanfaatkan iptek pada bidangnya dalam penyelesaian masalah serta mampu beradaptasi terhadap situasi yang dihadapi, (2) menguasai konsep teoretis bidang pengetahuan tertentu secara umum dan konsep teoretis bagian khusus dalam bidang pengetahuan tersebut secara mendalam, serta mampu memformulasikan penyelesaian masalah prosedural, (3) mampu mengambil keputusan yang tepat berdasarkan analisis informasi dan data, dan mampu memberikan petunjuk dalam memilih berbagai alternatif solusi secara mandiri dan kelompok, (4) bertanggung jawab pada pekerjaan sendiri dan dapat diberi tanggung jawab atas pencapaian hasil kerja organisasi. 
Berbagai penelitian mengenai e-modul telah banyak dikaji oleh para peneliti sebelumnya, misalnya penelitian dilakukan oleh Sugianto, dkk (2013) yang menunjukkan modul virtual memiliki tampilan yang menarik, mudah dipahami dan mudah digunakan.. Selanjutnya penelitian Gunawan (2014), bahwa e-modul Akuntansi yang dikembangkan untuk pembelajaran SMK program keahlian akuntansi memiliki efek potensial terhadap hasil belajar siswa dan peningkatan aktivitas belajar siswa. Hasil penelitian tersebut menunjukkan bahwa $e$ modul yang dikembangkan tergolong berhasil. Oleh karena itu peneliti ingin mengembangkan $e$-modul yang memiliki kekhasan berorientasi KKNI karena $e$-modul yang dikembangkan pada tingkat sekolah tinggi khususnya pada perkuliahan pendidikan kewarganegaraan.

Berdasarkan uraian tersebut, maka peneliti merasa sangat perlu untuk melakukan penelitian mengenai e-modul berorientasi KKNI dalam bentuk penelitian pengembangan yang dilaksanakan melalui prosedur dan ketentuan ilmiah.

\section{Metode}

Penelitian ini dilaksanakan di Fakultas Ilmu Komputer Universitas Sriwijaya dengan masa penelitian selama 1 (satu) tahun. Subjek penelitian yang ditetapkan adalah mahasiswa yang mengambil mata kuliah PKn pada semester Ganjil 2017-2018 yang akan ditetapkan dengan random sampling. Penelitian ini merupakan jenis penelitian dan pengembangan (research and development) menggunakan model ADDIE (analyze, design, development, implementation, evaluation) dan model lainnya. Model-model desain pembelajaran tersebut pada intinya menggunakan pendekatan sistem dan memiliki tujuan untuk menghasilkan produk pembelajaran yang efektif dan efisien.

Data dikumpulkan melalui teknik angket, dokumentasi, observasi dan tes. Selanjutnya teknik analisis data yang digunakan ialah analisis data kuantitatif. Selain data hasil studi pendahuluan, data angket yang berkaitan dengan validitas produk juga dianalisis dengan menggunakan analisis deskriptif.
Hasil data angket kemudian dikonversi ke dalam persentase untuk menentukan tanggapan validator terhadap e-modul berorientasi KKNI yang didasarkan pada kriteria penilaian data persentase. Selanjutnya, data validasi diinterpretasikan dalam bentuk kalimat yang bersifat kualitatif berdasarkan rata-rata data yang diperoleh dan kriteria data masing-masing. Analisis kuantitatif dilakukan untuk menganalisis hasil angket dan tes dengan menggunakan analisis nilai gain untuk melihat dampak potensial $e$ modul terhadap peningkatan perhatian dan pemahaman mahasiswa terhadap pembelajaran mata kuliah pendidikan kewarganegaraan pada saat uji coba.

\section{Hasil dan Pembahasan}

Penelitian pengembangan e-modul ini dimulai dari studi pendahuluan yang dilakukan dengan cara menganalisis fenomena serta hambatan yang dihadapi mahasiswa dalam mengikuti proses pembelajaran mata kuliah PKn. Salah satu alasan pengembangan e-modul ini adalah dalam konteks abad 21 ini warga negara harus mampu secara digital terlibat dan mengoperasikan perangkat-perangkat digital. Dalam kajian Pendidikan Kewarganegaraan, istilah itu disebut sebagai digital citizenship (kewarganegaraan digital). Kewarganegaraan digital diartikan sebagai aturan berperilaku warga negara di dunia digital. Lebih singkat dikatakan bahwa kewarganegaraan digital sebagai kemampuan untuk berpartisipasi dalam masyarakat online (Mossberger, Tolbert, \& McNeal, 2008). Kewarganegaraan digital juga diartikan kemampuan untuk menggunakan teknologi secara kompeten; menafsirkan dan memahami konten digital dan menilai kredibilitasnya; membuat, meneliti, dan berkomunikasi dengan alat yang tepat; berpikir kritis tentang peluang dan tantangan etika dunia digital; membuat pilihan online yang aman, bertanggung jawab, dan penuh hormat (Isman \& Gunggoren, 2014). Dengan demikian, kata kunci dari beberapa definisi di atas adalah adanya meliputi pengetahuan dan keterampilan untuk menggunakan teknologi secara tepat dalam dunia digital, mengelola risiko dan 
memanfaatkan peluang partisipatif yang ditawarkannya (Partnership for 21st Century Skills, 2014) Sementara itu warga negara digital mereka yang menggunakan Internet secara teratur dan efektif setiap hari (Mossberger et al., 2008).

Dengan demikian, diperlukan penyununan kurikulum Pendidikan Kewarganegaraan yang mengarahkan pada pencapaian KKNI. Kurikulum mencakup semua jenis kegiatan dalam pembelajaran yang dilakukan dalam tanggung jawab sekolah sesuai dengan tujuan sekolah (Doğanay, 2012). Dalam praktiknya, kurikulum terdiri dari sejumlah rencana, dalam bentuk tertulis dan berbagai lingkup, yang menggambarkan pengalaman belajar yang diinginkan. Kurikulum sekolah harus mengembangkan komitmen untuk belajar yang menyenangkan dan sebagai sarana untuk pencapaian tertinggi (optimal) untuk semua siswa (White, 2004).

Kurikulum Pendidikan kewarganegaraan harus membantu siswa memperoleh dan belajar menggunakan pengetahuan, keterampilan, nilai-nilai dan sikap yang akan membantu mereka menjadi warga negara yang aktif yang dibutuhkan dalam masyarakat demokratis.

Langkah menyusun $e$-modul ini diawali dengan menyusun purwarupa $e$-modul dengan memperhatikan aspek muatan materi, dan bahasa. Purwarupa yang dihasilkan kemudian diberikan kepada ahli bahasa dan materi untuk di validasi. Validasi bahasa terdiri dari lima aspek yang dinilai menghasilkan skor 92\%, berarti dinyatakan valid. Kemudian validasi materi dilakukan berdasarkan enam aspek penilaian, hasil validasi memperoleh skor $92 \%$ dengan kesimpulan dinyatakan valid. Hasil validasi yang dinyatakan valid kemudian diperbaiki sesuai saran ahli diantaranya memperbaiki kalimat yang tidak baku menjadi kalimat baku ke dalam $e$-modul berorientasi KKNI tersebut dan lebih dijelaskan bagaimana materi yang berorientasi KKNI.

Setelah diperbaiki sesuai saran ahli materi kemudian $e$-modul tersebut dilakukan uji coba kepada tiga orang mahasiswa yang dipilih berdasarkan kategori nilai tinggi, sedang dan rendah. Dari hasil uji coba tersebut, diperoleh tanggapan sebesar $81 \%$ dari uji coba tahapan one to one, hal tersebut menunjukkan bahwa media pembelajaran yang dikembangkan oleh tim peneliti termasuk kategori valid. Namun demikian walaupun sudah terkategori valid ada beberapa poin yang menjadi masukan dari tahapan one to one ini yaitu: (1) bahasa yang tidak baku; dan (2) kalimat petunjuk yang tidak jelas.

Setelah di revisi berdasarkan hasil uji coba one to one, maka e-modul tersebut kemudian dilakukan uji coba kepada kelompok kecil yang terdiri dari lima mahasiswa yang dipilih berdasarkan kategori nilai tinggi, sedang dan rendah. Berdasarkan hasil penelaahan yang dilakukan oleh mahasiswa pada tahapan uji coba kelompok kecil ini, maka diperoleh tanggapan sebesar 82,1 \%, hal tersebut menunjukkan bahwa media pembelajaran yang dikembangkan oleh tim peneliti termasuk kategori valid setelah diuji coba pada kelompok kecil. Pada tahap ini juga dilakukan observasi terhadap pembelajaran di kelas, hasilnya dapat dilihat pada tabel berikut.

Aktivitas mahasiswa pada tahap uji coba ini sebesar 64\% maka dapat ditarik kesimpulan bahwa pada tahapan ini mahasiswa tergolong aktif.

Berdasarkan hasil review dan observasi yang dilakukan pada uji coba kelompok kecil maka dapat disimpulkan bahwa modul pembelajaran yang dikembangkan tim peneliti sudah memenuhi unsur validitas serta membuat mahasiswa berperan aktif selama proses pembelajaran mata kuliah pendidikan kewarganegaraan. Karena itulah media pembelajaran yang dikembangkan ini akan dilanjutkan untuk uji coba lapangan pada seluruh mahasiswa di kelas. Tahapan ini dibuat menyerupai situasi pembelajaran yang sebenarnya dengan maksud jika produk tersebut telah dinilai layak maka dapat digunakan pada khalayak lainnya.

Tahapan uji coba lapangan dimulai dengan pemberian tes awal (pre-test) sebanyak 15 butir soal pilihan ganda kepada mahasiswa yang dijadikan objek penelitian, hal ini dimaksudkan untuk mengukur kemampuan awal mahasiswa berkaitan dengan materi pendidikan kewarganegaraan. 
Selanjutnya di akhir proses pembelajaran diadakan posttest. Skor dari tes tersebut disajikan pada tabel berikut ini.

Tabel Hasil Pre-tes dan Post-test

\begin{tabular}{|c|c|c|c|}
\hline No & Nama & Pretest & posttest \\
\hline I. & M. Taufik Hidayat & 40 & 67 \\
\hline 2. & Syekh Abdullah & 40 & 67 \\
\hline 3. & M. Aji Ma'ruf & 67 & 87 \\
\hline 4. & Hanni Septia & 53 & 73 \\
\hline 5. & Kiki Arifudin & 27 & 67 \\
\hline 6. & Alfin Mulya Pradana & 53 & 73 \\
\hline 7. & Ainsya Arbahori & 67 & 67 \\
\hline 8. & $\begin{array}{c}\text { Tantri Langgeng } \\
\text { Widodo }\end{array}$ & 73 & 73 \\
\hline 9. & Farhan Ali & 53 & 87 \\
\hline I0. & Zumardi Irfan & 60 & 93 \\
\hline II. & Wahyu Hasrakhan & 67 & 87 \\
\hline $\mathrm{I} 2$. & Yoga Faturrahman & 47 & 67 \\
\hline \multirow[t]{3}{*}{$\mathrm{I} 3}$. & Tiara Nu’Azmi Pupa & 53 & 80 \\
\hline & Total & 700 & 1008 \\
\hline & Rata-Rata & 53,9 & 77,6 \\
\hline
\end{tabular}

Sumber: data diolah penulis, 2018.

Data tabel menyatakan rata-rata skor pretest sebesar 53,9, sedangkan nilai posttest rata-ratanya sebesar 77,6. Maka dapat disimpulkan bahwa terdapat peningkatan sebesar 23,7 dan di dapatkan N-Gain sebesar 0,6 dengan kategori sedang. Hal tersebut menunjukkan bahwa e-modul ini memiliki efek potensial terhadap pemahaman mahasiswa terhadap materi perkuliahan pendidikan kewarganegaraan. Pada tahapan uji coba lapangan juga menggunakan angket untuk melihat tanggapan mahasiswa mengenai $e$-modul yang telah dikembangkan, hasilnya terlihat pada tabel berikut ini.

Tabel 2. Rekapitulasi Angket Tahap Field Evaluation

\begin{tabular}{|c|c|c|c|c|c|c|c|c|}
\hline \multirow{2}{*}{ No } & \multirow{2}{*}{ Nama } & \multicolumn{7}{|c|}{ Item } \\
\hline & & 1 & 2 & 3 & 4 & 5 & 6 & 7 \\
\hline I. & $\begin{array}{l}\text { M. Taufik } \\
\text { Hidayat }\end{array}$ & 3 & 3 & 4 & 4 & 4 & 3 & 4 \\
\hline 2. & $\begin{array}{c}\text { Syekh } \\
\text { Abdullah }\end{array}$ & 3 & 3 & 3 & 4 & 3 & 4 & 3 \\
\hline 3. & M. Aji Ma'ruf & 4 & 4 & 4 & 4 & 4 & 3 & 3 \\
\hline 4. & Hanni Septia & 3 & 3 & 4 & 4 & 4 & 4 & 4 \\
\hline 5. & Kiki Arifudin & 3 & 4 & 3 & 3 & 3 & 3 & 3 \\
\hline 6. & $\begin{array}{c}\text { Alfin Mulya } \\
\text { Pradana }\end{array}$ & 3 & 3 & 4 & 4 & 4 & 3 & 3 \\
\hline 7. & $\begin{array}{l}\text { Ainsya } \\
\text { Arbahori }\end{array}$ & 3 & 3 & 4 & 4 & 4 & 4 & 4 \\
\hline 8. & $\begin{array}{c}\text { Tantri } \\
\text { Langgeng } \\
\text { Widodo }\end{array}$ & 3 & 3 & 3 & 3 & 4 & 3 & 4 \\
\hline 9. & Farhan Ali & 3 & 3 & 4 & 4 & 4 & 4 & 4 \\
\hline IO. & Zumardi Irfan & 3 & 3 & 3 & 3 & 3 & 3 & 3 \\
\hline II. & $\begin{array}{c}\text { Wahyu } \\
\text { Hasrakhan }\end{array}$ & 3 & 2 & 4 & 3 & 4 & 3 & 3 \\
\hline $\mathrm{I} 2$. & $\begin{array}{l}\text { Yoga } \\
\text { Faturrahman }\end{array}$ & 3 & 3 & 4 & 4 & 4 & 4 & 4 \\
\hline
\end{tabular}

\begin{tabular}{|c|c|c|c|c|c|c|c|c|}
\hline I3. & $\begin{array}{c}\text { Tiara } \\
\text { Nu'Azmi } \\
\text { Pupa }\end{array}$ & 4 & 4 & 4 & 4 & 4 & 3 & 3 \\
\hline I4. & $\begin{array}{l}\text { Galang } \\
\text { Hazelda }\end{array}$ & 4 & 2 & 3 & 4 & 4 & 3 & 4 \\
\hline 15. & $\begin{array}{l}\text { Sevanus } \\
\text { William }\end{array}$ & 3 & 4 & 3 & 3 & 3 & 3 & 3 \\
\hline & Total & 48 & 47 & 54 & 55 & 56 & 50 & $5 \mathrm{I}$ \\
\hline
\end{tabular}

Sumber: data diolah penulis, 2018.

Berdasarkan tabel, rata-rata tanggapan mahasiswa yang menggunakan e-modul ini dikategorikan sangat baik dengan nilai sebesar $85.94 \%$. Menurut mahasiswa yang menggunakan $e$-modul ini menyatakan bahwa e-modul berorientasi KKNI sangat membantu dalam mempelajari materi perkuliahan dikarenakan praktis dan menarik dengan berbagai efek yang ada di $e$-modul tersebut

Selanjutnya melihat keaktifan mahasiswa selama proses pembelajaran menggunakan $e$ modul berorientasi KKNI, digunakan juga teknik observasi, hasil observasi diperoleh hasil sebesar $66,64 \%$ sehingga dapat disimpulkan bahwa keaktifan mahasiswa selama proses pembelajaran menggunakan $e$ modul berorientasi KKNI tersebut berada pada kategori aktif.

Untuk menunjang proses pembelajaran agar tercapai tujuannya dan mampu menghasilkan pemahaman yang baik salah satunya ialah dengan mempersiapkan $e$-modul yang mampu memotivasi peserta didik untuk turut aktif dalam proses pembelajaran yang disusun membantu siswa untuk mencapai sejumlah tujuan pembelajaran (Daryanto \& Aris, 2014). Dalam konteks kajian pendidikan kewarganegaraan, mahasiswa sebagai warga negara muda pada abad 21 harus memiliki apa yang diharapkan dari pendidikan kewarganegaraan untuk membantu orangorang muda memperoleh dan mengaplikasikan keterampilan, pengetahuan, dan sikap yang akan mempersiapkan mereka untuk menjadi warga negara yang kompeten dan bertanggung jawab dalam kehidupan berdemokrasi. Harapan pendidikan kewarganegaraan ke depan mampu untuk menekankan upaya yang sama pada (1) pengetahuan dan pemahaman demokratis, nilai-nilai demokratis, sikap dan kesadaran umum. Kompetensi ini harus disertai dengan keterampilan praktis seperti pemecahan masalah, solusi konflik, pembelajaran 
layanan, kewirausahaan dan keterlibatan di dalam masyarakat (Himmelmann, 2013). Dari rumusan harapan pendidikan kewarganegaraan di atas, terlihat penekanan pada pemahaman, penanaman, dan implementasi demokrasi bagi warga negara

Agar tujuan pembelajaran selaras dengan kerangka kualifikasi nasional Indonesia maka, $e$-modul yang dikembangkan berorientasi dengan KKNI berdasarkan Peraturan Presiden Nomor 8 Tahun 2012 tentang Kerangka Kualifikasi Nasional Indonesia yang menyandingkan, menyetarakan, dan mengintegrasikan sektor pendidikan dengan sektor pelatihan dan pengalaman kerja dalam suatu skema pengakuan kemampuan kerja yang disesuaikan dengan struktur di berbagai sektor pekerjaan. Peraturan presiden mengenai KKNI menjelaskan bahwa lulusan setara S1 harus memiliki beberapa kompetensi antara lain: (1) Mampu mengaplikasikan bidang keahliannya dan memanfaatkan iptek yang dihadapi, (2) Menguasai konsep teoretis bidang pengetahuan tertentu secara umum dan konsep teoretis bagian khusus dalam bidang pengetahuan tersebut secara mendalam, serta mampu memformulasikan penyelesaian masalah prosedural, (3) Mampu mengambil keputusan yang tepat berdasarkan analisis informasi dan data, dan mampu memberikan petunjuk dalam memilih berbagai alternatif solusi secara mandiri dan kelompok, (4) Bertanggung jawab pada pekerjaan sendiri dan dapat diberi tanggung jawab atas pencapaian hasil kerja organisasi. Dengan demikian, setiap pembahasan dalam modul berorientasi pada 4 kompetensi lulusan S1 yang dimuat dalam KKNI tersebut.

Penggunaan berbagai macam aplikasi dalam mengembangkan $e$-modul berorientasi KKNI sangat baik untuk dimanfaatkan. Sehinga tampilan e-modul dapat lebih menarik dan atraktif, selain itu juga dapat menambah keefektifan dan keefisienan $e$ modul tersebut sebagaimana capaian pembelajaran secara umum yang mencakup aspek-aspek pembangun jati diri bangsa, penguasaan ilmu pengetahuan dan teknologi, kemampuan untuk dapat melakukan kerja secara bermutu, serta wewenang dan kewajiban seseorang sesuai dengan level kualifikasinya. Aspek pembangun jati diri bangsa tercermin dalam Pancasila, UndangUndang Dasar 1945, dan Bhineka Tunggal Ika yaitu menjunjung tinggi pengamalan kelima sila Pancasila dan penegakan hukum, serta mempunyai komitmen untuk menghargai keragaman agama, suku, budaya, bahasa, dan seni yang tumbuh dan berkembang di bumi Indonesia (Direktorat Pembelajaran dan Kemahasiswaan, 2014).

\section{Simpulan}

Berdasarkan data-data yang didapatkan selama penelitian maka dapat disimpulkan jika e-modul berorientasi KKNI yang dikembangkan ini valid, praktis dan berefek potensial dalam meningkatkan pemahaman mahasiswa terhadap materi perkuliahan pendidikan kewarganegaraan. Terkategorikan valid setelah mendapatkan hasil $92 \%$ dari validasi ahli bahasa dan $92 \%$ dari ahli materi. Kemudian dalam tiga kali tahapan uji coba mendapatkan tanggapan yang positif dari para mahasiswa penggunaannya. Dan pada uji coba lapangan terdapat $\mathrm{N}$-Gain sebesar 0,6 dengan kategori sedang dari perbandingan pre tes dan pos tes yang dilakukan. Namun kelemahan e-modul berorientasi KKNI ini ialah tidak kompatibel di semua perangkat sehingga hanya perangkat lunak tertentu saja yang bisa memakai aplikasi multimedia tersebut.

\section{Referensi}

Daryanto, \& Aris. (2014). Pengembangan perangkat embelajaran. Yogyakarta: Gaya Media.

Direktorat Pembelajaran dan Kemahasiswaan. (2014). Panduan penyusunan capaian pembelajaran lulusan program studi. Jakarta: Direktorat Jenderal Pendidikan Tinggi Kementerian Pendidikan Dan Kebudayaan.

Doğanay, A. (2012). A curriculum framework for active democratic citizenship education. In M. Print \& D. Lange (Ed.), Schools, Curriculum and Civic Education for Building Democratic Citizens (hal. 19-39). Roterdam, Boston, Taipe: Sense Publisher. 
Himmelmann, G. (2013). Competences for teaching, learning and living democratic citizenship. In Civic education and competences for engaging citizens in democracies (hal. 3-7). Roterdam/Boston/Taipe: Sense Publishers.

Isman, A., \& Gunggoren, O. C. (2014). Digital citizenship. TOJET: The Turkish Olnline Joornal od Education Technology, 13(1), 73-77.

Mossberger, K., Tolbert, C. J., \& McNeal, R. S. (2008). Digital citizenship. The internet, society, and participation. Cambridge, Massachusetts London, England: The MIT Press.

Partnership for 21st Century Skills. (2014). Reimagining citizenship for the 21st century: a call to action for policymakers and educators. Diambil dari http://www.p21.org/storage/documents/ Reimagining_Citizenship_for_21st_Cen tury_webversion.pdf

Sugianto, D., Abdullah, A. G., Elvyanti, S., \& Muladi, Y. (2013). Modul virtual: Multimedia flipbook dasar teknik digital. Invotec, IX(2), 16.

White, J. (Ed.). (2004). Rethinking the school curriculum. Values, aims and purposes. London and New York: Routledge Falmer.

https://doi.org/10.4324/9780203618523 